\title{
HUBUNGAN ANTARA ANGKA KECUKUPAN ENERGI DAN PROTEIN DENGAN KESEMBUHAN LUKA PADA PASIEN ULKUS DEKUBITUS
}

\author{
Nathalia Safitri $^{1}$, Hertanto Wahyu Subagio ${ }^{2}$, Etisa Adi Murbawani ${ }^{3}$, \\ Niken Puruhita ${ }^{4}$, Amalia Sukmadianti ${ }^{5}$ \\ ${ }^{1}$ PPDS-1 Gizi Klinis, Fakultas Kedokteran Universitas Diponegoro/RSUP Dr. Kariadi Semarang \\ ${ }^{2,3,4,5}$ Staf Bagian Gizi Klinis, Fakultas Kedokteran Universitas Diponegoro, Semarang \\ *corresponding author, contact: nathaliasafitri@gmail.com
}

\begin{abstract}
Abstrak
Latar belakang : Ulkus dekubitus merupakan masalah kesehatan di banyak negara dan malnutrisi merupakan salah satu faktor yang berpengaruh, namun investigasi klinis masih jarang dilakukan untuk mengamati kebutuhan jumlah energi dan protein pada kesembuhan luka.

Tujuan penelitian : Menganalisis hubungan antara angka kecukupan energi dan protein dengan kesembuhan luka pada pasien ulkus dekubitus. Menganalisis hubungan antara angka kecukupan energi dan protein dengan kesembuhan luka pada pasien ulkus dekubitus dikontrol dengan faktor usia, indeks massa tubuh, dan adanya infeksi.

Metode penelitian : Studi observasional dengan pendekatan cross sectional melibatkan 40 pasien ulkus dekubitus dengan fungsi ginjal normal dan tidak menderita diabetes melitus. Kesembuhan luka dinilai menggunakan PUSH score tools 3.0, angka kecukupan energi dan angka kecukupan protein dinilai berdasarkan rata-rata asupan total masing-masing yang diberikan dalam seminggu.

Hasil : Terdapat hubungan lemah antara angka kecukupan energi dengan kesembuhan luka ( $\mathrm{r}=0,37$ dan $p=0,02$ ). Adanya hubungan sedang antara angka kecukupan protein dengan kesembuhan luka $(\mathrm{r}=0,42$ dan $p=0,01)$.

Simpulan : Terdapat hubungan bermakna antara angka kecukupan energi dan protein dengan kesembuhan luka pada pasien ulkus dekubitus. Faktor usia, indeks massa tubuh, dan infeksi pada ulkus dekubitus bukan merupakan variabel perancu dalam penelitian ini.
\end{abstract}

Kata kunci : Angka kecukupan energi, angka kecukupan protein, kesembuhan luka, ulkus dekubitus.

\begin{abstract}
Background : Pressure ulcers are a health problem in many countries and malnutrition is one of factors that impact the development of pressure ulcers but clinical investigations are still rarely carried out to observe the required amount of enetgy and protein in wound healing process.

Objective : Analyzing the relevance between energy and protein adequacy rate with wound process in pressure ulcers patients. Analyzing the relevance between energy and protein adequacy rate with wound process in pressure ulcers patients controlled by factors of age, body mass index, and presence of infection.

Research method : Observational study with cross sectional approach involved 40 patients pressure ulcers with normal kidney function and without diabetes mellitus condition Wound healing was assessed using PUSH score tool 3.0, the energy and protein adequacy rate were assessed based on the average of total intake of each given in a week

Results : A weak correlation between energy adequacy rate and wound healing process $(r=0,37)$. Moderate correlation between protein adequacy rate and wound healing process $(\mathrm{r}=0,42)$.

Conclusion : There is a significant relevance between energy and protein adequacy rates with wound healing process in patients with pressure ulcers. Age, body mass index, and infection were not confounding variables in this study.
\end{abstract}

Keyword : Energy adequeacy rate, protein adequacy rate, wound healing, pressure ulcers 


\section{Latar Belakang}

Ulkus dekubitus merupakan masalah yang terjadi di lingkungan kesehatan baik di Amerika Serikat (AS), Eropa, dan negara lainnya. Kejadian ini dapat menurunkan kualitas hidup secara global, mempercepat terjadinya mortalitas, dan meningkatkan beban biaya pada organisasi kesehatan. ${ }^{1}$ Dimulai sejak 5 hingga 6 tahun terakhir, fasilitas kesehatan telah meningkatan fokus untuk mencegah terjadinya ulkus dekubitus dan mengurangi angka kejadian nosokomial ulkus dekubitus sebagai indikator kualitas bagi fasilitas kesehatan tersebut. ${ }^{2}$

Berdasarkan data dari International Pressure Ulcer Prevalence Study ( IPUPS ) prevalensi ulkus dekubitus pada tahun 2005 pada 651 fasilitas kesehatan di Amerika Serikat didapatkan 3.027 pasien dengan ulkus dekubitus dari total sampel 85.838 ( 15 $\%$ ) dimana lebih dari 2/3 kasus merupakan ulkus dekubitus derajat I dan II. ${ }^{2}$

Penelitian Purwaningsih menyebutkan angka kejadian dekubitus di Rumah Sakit dr. Sardjito Yogyakarta sebesar $40 \%$ dari 40 pasien yang mengalami tirah baring. Penelitian Setyajati di Rumah Sakit dr. Moewardi Surakarta mendapatkan angka kejadian ulkus dekubitus $38.18 \%$ dari pasien yang mengalami tirah baring. Hal tersebut menunjukkan bahwa angka kejadian dekubitus pada pasien tirah baring lama di rumah sakit cukup tinggi. Penelitian yang dilakukan oleh Arif Widodo di Rumah Sakit Islam Surakarta menguraikan bahwa ulkus dekubitus lebih sering terjadi pada usia 25-65 tahun yaitu sebanyak $62.5 \%$ dan menyebutkan bahwa jenis kelamin tidak berpengaruh terhadap kejadian ulkus dekubitus. $^{3}$

The National Pressure Ulcer Advisory Panel (NPUAP) dan European Pressure Ulcer Advisory Panel (EPUAP) mendefinisikan ulkus dekubitus sebagai luka yang terlokalisir pada kulit atau jaringan di bawahnya yang biasanya terletak pada tonjolan tulang akibat dari tekanan atau kombinasi antara tekanan dan gesekan. ${ }^{4}$ Proses kesembuhan luka pada ulkus dekubitus terdiri dari fase inflamasi, fase proliferatif, dan fase remodeling yang prosesnya dipengaruhi oleh asupan gizi. Asupan yang suboptimal mempengaruhi proses sintesis kolagen, sistem imun, dan kekuatan regangan pada jaringan yang akan beregenerasi. ${ }^{1}$ Keberhasilan penyembuhan luka pada pasien ulkus dekubitus dapat dinilai dari peningkatan granulasi jaringan, ukuran dan kedalaman luka yang berkurang, dan jumlah eksudat maupun jaringan nekrotik yang semakin sedikit. ${ }^{5}$

Penilaian kesembuhan luka pada ulkus dekubitus menggunakan Pressure Ulcers Scale for Healing (PUSH) score yang 
menilai 3 parameter yaitu penilaian luas ulkus, didapatkan ada atau tidaknya eksudat pada ulkus, dan jenis jaringan pada luka dimana masing-masing memiliki poin yang kemudian digunakan untuk menilai kesembuhan luka pada ulkus dekubitus. Skor PUSH ini memiliki total nilai terendah 0 dan nilai tertinggi 17 dimana semakin rendah total nilai dibandingkan dengan penilaian pertama menunjukkan adanya proses kesembuhan luka pada ulkus dekubitus. $^{6}$

Malnutrisi merupakan salah satu faktor yang berpengaruh dalam perkembangan ulkus dekubitus namun sangat sedikit investigasi klinis yang telah dilakukan untuk mengamati jumlah energi dan protein yang dibutuhkan untuk menyembuhkan ulkus dekubitus. ${ }^{5}$ Berdasarkan acuan EPUAP kebutuhan energi untuk proses kesembuhan luka pada ulkus dekubitus adalah 30-35 kkal/kgbb/hari dan kebutuhan protein untuk proses kesembuhan luka pada ulkus dekubitus stadium I dan II adalah 1.25-1.5 gr/kgbb/hari. Kebutuhan protein untuk proses kesembuhan luka pada ulkus dekubitus stadium III dan IV adalah 1.5-2 gr/kgbb/hari ${ }^{1,4-7}$

Angka kejadian ulkus dekubitus menjadi penting karena berhubungan dengan perawatan dan kualitas pelayanan pasien, Rumah Sakit Umum Pusat (RSUP) dr Kariadi Semarang sebagai salah satu rumah sakit rujukan di Jawa Tengah merupakan rumah sakit yang menerima banyak pasien setiap harinya sehingga diperlukan peningkatan kualitas pelayanan dan mutu rumah sakit. Data yang didapat dari penelitian ini diharapkan dapat membantu memberikan gambaran dan peran gizi klinis kepada pihak-pihak terkait seperti perawat, dokter, dan pihak rumah sakit untuk meningkatkan kualitas pelayanan pasien dengan tirah baring lama

\section{Metode}

Penelitian ini merupakan penelitian cross sectional dengan cara pengambilan sampel menggunakan consecutive sampling. Penelitian dilakukan terhadap 40 subjek pasien ulkus dekubitus yang dirawat di bangsal Rajwali, bangsal Geriatri, Intensive Care Unit (ICU), dan High Care Unit (HCU) RSUP dr Kariadi Semarang yang berusia 18-60 tahun, tidak merokok dan tidak mengkonsumsi alkohol dalam 1 tahun terakhir, mendapatkan obat-obatan (NASIDs/kortikosteroid/kemoterapi),dan mendapatkan terapi gizi dari dokter spesialis gizi klinis.

Kriteria eksklusi dalam penelitian ini adalah subjek dengan kadar kreatinin diatas nilai normal, memiliki riwayat penyakit 
diabetes melitus, dan meninggal sebelum 7 hari perawatan.

Variabel tergantung pada penelitian ini adalah kesembuhan luka pada ulkus decubitus yang dinilai menggunakan skor PUSH 3.0 yang dibandingkan pada hari pertama pengamatan dan hari ketujuh pengamatan. Angka kecukupan energi dan protein merupakan variabel bebas yang didapat dari rerata asupan energi per hari yang dihitung dari jumlah asupan energi total dalam 1 minggu dibagi 7 (kkal/hari) yang ditampilkan dalam bentuk angka ratarata asupan dibandingkan target energi. Angka kecukupan protein dihitung berdasarkan rerata asupan energi per hari yang dihitung dari jumlah asupan protein total dalam 1 minggu dibagi 7 (gram.hari) yang ditampilkan dalam bentuk angka ratarata asupan dibandingkan target protein.

Data dianalisis dengan menggunakan perangkat lunak komputer. Analisis data dilakukan dengan menggunakan metode analisis korelasi bivariat untuk menganalisis korelasi antar variabel yang diteliti. Analisis data meliputi : uji deskriptif (jumlah dan persentase), uji hipotesis dengan analisis korelasi Pearson (nilai $\mathrm{p}<0.05$, nilai $\mathrm{r}$ dengan interval kepercayaan 95\%.) Jika syarat tidak terpenuhi, maka dipergunakan uji korelasi Spearman. Hasil uji analisis bivariat didapatkan hasil signifikan dan dilanjutkan analisis multivariat dengan regresi multipel

\section{Hasil Penelitian}

Data karakteristik subjek penelitian diuraikan pada Tabel 1. dengan distribusi normal ditunjukkan dengan rerata \pm SD (simpang deviasi), sedangkan data dengan distribusi tidak normal ditunjukkan dengan median (nilai minimum; maksimum). Distribusi variabel penelitian ditunjukkan pada Tabel 2. Rerata usia subjek penelitian ini adalah $43.2 \pm 12.64$ tahun dengan jenis kelamin wanita sebanyak 55\% $(\mathrm{n}=22)$ dan laki-laki sebanyak 45\%(n=18). Penelitian ini melibatkan pasien dengan usia 18-60 tahun dengan kadar kreatinin serum normal dan tidak memiliki penyakit diabetes melitus tipe II dengan terapi gizi klinis target energi 35$40 \mathrm{kkal} / \mathrm{kgBB} / \mathrm{hari}$ dan target protein $>1.2$ gr/kgBB/hari. Kategori IMT didominasi pasien dengan berat badan kurang sebesar $47.5 \%(n=19)$, berat badan normal sebesar $22.5 \%(n=9)$, berat badan berlebih sebesar $10 \%(n=4)$, dan obesitas sebesar $20 \%(n=8)$. Hal ini sesuai dengan pernyataan dari The National Pressure Ulcer Long-Term Care Study dimana penurunan berat badan dan kondisi malnutrisi meningkatkan risiko terjadinya ulkus dekubitus. ${ }^{1}$

Skor PUSH pada hari pertama dilakukan penilaian $(\mathrm{H} 0)$ berkisar $10.1 \pm 3.60$ dimana pada hari ketujuh saat dilakukan 
evaluasi (H7) didapatkan skor PUSH berkisar antara 3-15. Rerata angka kecukupan energi pada pasien dalam jangka $\begin{array}{llll}\text { waktu } & \mathrm{H} 0-\mathrm{H} 7 & \text { yaitu } & 30.8 \pm 7.35\end{array}$ $\mathrm{kkal} / \mathrm{kgBB} / \mathrm{hari}$ dengan rentang nilai minimal hingga maksimal angka kecukupan protein 0.6-1.5 g/kgBB/hari. Jumlah leukosit pada subjek penelitian di antara 6800-17.800 103/uL dan angka kesembuhan berkisar 1-4.

Analisis hubungan antara usia, berat badan, tinggi badan, IMT, skor PUSH H-0 dan H-7, angka kecukupan energi dan protein, jumlah leukosit dengan kesembuhan luka dilakukan menggunakan uji Spearman. Hubungan tersebut dapat dilihat pada Tabel 3.

Angka kecukupan energi berdistribusi normal, sedangkan angka kesembuhan luka berdistribusi tidak normal. Data tersebut dilakukan transformasi data dan dilakukan uji normalitas Saphiro-Wilk, didapatkan distribusi data yang tidak normal sehingga digunakan uji korelasi Spearman. Analisis bivariat menunjukkan terdapat hubungan lemah $(\mathrm{r}=0.2-0.4)$ antara angka kecukupan energi dengan kesembuhan luka $(r=0.37)$.

Analisis bivariat skor PUSH H-0 berkorelasi dengan kesembuhan luka $(p=0.21) \quad$ sehingga dilakukan analisis multivariat untuk mengontrol angka kecukupan energi dan angka kecukupan protein dengan skor PUSH H-0 terhadap kesembuhan luka pada pasien ulkus dekubitus. Hasil multivariat menunjukkan bahwa angka kecukupan energi secara signifikan $(\mathrm{p}=0.03)$ berhubungan dengan kesembuhan luka pada pasien ulkus dekubitus setelah dikontrol dengan skor PUSH H-0. Angka kecukupan protein secara signifikan $(\mathrm{p}=0.01)$ berhubungan dengan kesembuhan luka pada pasien ulkus dekubitus setelah dikontrol dengan skor PUSH H-0.

Uji analisis menggunakan regresi linier berganda dari data uji korelasi yang memiliki nilai $\mathrm{p}<0.25$ yaitu meliputi skor PUSH H-0, angka kecukupan energi, dan angka kecukupan protein terhadap kesembuhan luka yang dapat dilihat pada Tabel 4 dan Tabel 5.

Hasil analisis multivariat angka kecukupan energi menunjukkan kontribusi sebesar $11 \%$ terhadap kejadian kesembuhan luka yang dikontrol dengan penilaian skor PUSH H-0. Angka kecukupan protein memiliki kontribusi sebesar 18\% terhadap kejadian kesembuhan luka yang dikontrol dengan PUSH skor $\mathrm{H}-0$ berdasarkan analisis penelitian ini.

\section{Pembahasan}

Salah satu aspek penting dalam pelayanan rumah sakit adalah perawatan pasien secara holistik dimana ulkus 
dekubitus merupakan komplikasi yang sering terjadi pada pasien dengan perawatan tirah baring lama dan berpengaruh terhadap kualitas pelayanan rumah sakit. ${ }^{3}$ Banyak studi penelitian yang menunjukkan malnutrisi sebagai faktor signifikan dalam perkembangan ulkus dekubitus. ${ }^{5}$ Studi penelitian ini mengamati kebutuhan asupan energi dan protein terhadap kesembuhan luka pada pasien dengan ulkus dekubitus.

Distribusi karakterisitik subjek pada kedua kelompok disajikan pada Tabel 1 . dimana jenis kelamin wanita lebih banyak dibandingkan laki - laki. Berat badan kurang merupakan prevalensi terbesar (47.5\%) dibandingkan kategori IMT lain. Ulkus dekubitus derajat I yang paling banyak didapatkan pada penelitian ini dengan kondisi luka tanpa infeksi sebesar 57.5\%. Pasien yang mendapatkan asupan energi $\geq$ $30 \mathrm{kkal} / \mathrm{kgBB} / \mathrm{hari}$ sebanyak 27 orang dan yang mendapatkan asupan protein $\geq 1.2$ $\mathrm{gP} / \mathrm{kgBB} /$ hari sebanyak 24 orang. Diagnosis penyakit stroke sebesar $25 \%$, kanker $12.5 \%$, dan lain-lain $47.5 \%$.

Rerata usia subjek penelitian ini adalah 43.2 \pm 12.64 tahun dengan jenis kelamin wanita sebanyak $55 \%(n=22)$ dan laki-laki sebanyak $45 \%(n=18)$. Penelitian ini melibatkan pasien dengan usia 18-60 tahun dengan kadar kreatinin serum normal dan tidak memiliki penyakit diabetes melitus tipe
II dengan terapi gizi klinis target energi 35$40 \mathrm{kkal} / \mathrm{kgBB} / \mathrm{hari}$ dan target protein $>1.2$ gr/kgBB/hari. Kategori IMT didominasi pasien dengan berat badan kurang sebesar $47.5 \%(n=19)$, berat badan normal sebesar $22.5 \%(n=9)$, berat badan berlebih sebesar $10 \%(n=4)$, dan obesitas sebesar 20\% ( $n=8)$. Hal ini sesuai dengan pernyataan dari The National Pressure Ulcer Long-Term Care Study dimana penurunan berat badan dan kondisi malnutrisi meningkatkan risiko terjadinya ulkus dekubitus. ${ }^{1}$

Analisis bivariat menunjukkan terdapat hubungan lemah $(\mathrm{r}=0.2-0.4)$ antara angka kecukupan energi dengan kesembuhan luka $(r=0.37)$ Angka kecukupan energi pada penelitian ini dinilai dari rerata asupan energi per hari dihitung selama 1 minggu selama rentang waktu pengamatan. Pemenuhan kebutuhan makronutrien dapat diberikan secara oral, enteral, dan formula parenteral yang mengandung karbohidrat, lemak, dan protein. ${ }^{1,5}$

Kesembuhan luka pada ulkus dekubitus merupakan proses kompleks yang terjadi secara simultan dan merupakan interaksi antar sel dan mediator kimiawi tubuh akibat dari luka yang terlokalisir di kulit atau jaringan di bawahnya yang umumnya terletak pada tonjolan tulang akibat dari tekanan atau kombinasi 
keduanya. ${ }^{4,8,9}$ Glukosa yang merupakan karbohidrat sederhana merupakan energi dasar dalam aktivitas selular. ${ }^{1}$

Kesembuhan luka pada ulkus dekubitus merupakan proses kompleks yang terjadi secara simultan dan merupakan interaksi antar sel dan mediator kimiawi tubuh akibat dari luka yang terlokalisir di kulit atau jaringan di bawahnya yang umumnya terletak pada tonjolan tulang akibat dari tekanan atau kombinasi keduanya., ${ }^{4,9}$ Glukosa yang merupakan karbohidrat sederhana merupakan energi dasar dalam aktivitas selular. ${ }^{1}$

Hasil penelitian ini sesuai dengan studi yang dilakukan di Pusat Medis Nagasaki pada bulan Agustus 2007-Februari 2008 yang melibatkan 40 subjek pasien dengan ulkus dekubitus menunjukkan 21 orang yang mengalami kesembuhan luka selalu mendapatkan asupan energi lebih dari $30 \mathrm{kkal} / \mathrm{kgBB} / \mathrm{hari}$ dan 19 orang yang mengalami gangguan kesembuhan luka mendapat asupan tidak lebih dari 20 $\mathrm{kkal} / \mathrm{kgBB} / \mathrm{hari}$ selama periode penelitian. ${ }^{5}$ Studi lain juga menyebutkan estimasi kebutuhan energi dalam proses kesembuhan luka berkisar $30 \mathrm{kkal} / \mathrm{kgBB} / \mathrm{hari}$ dan untuk menjaga balans nitrogen positf dibutuhkan energi 30-35 kkal/kgBB/hari. ${ }^{1}$

Evaluasi efek intervensi gizi pada pasien ulkus dekubitus yang dilakukan oleh
Ohura Takehiko dkk. dengan studi kontrol acak selama 12 minggu menunjukkan pemberian rata-rata energi pada kelompok kontrol sebesar $29.1 \mathrm{kkal} / \mathrm{kgBB} / \mathrm{hari}$ dan kelompok perlakuan sebesar 37.9 $\mathrm{kkal} / \mathrm{kgBB} / \mathrm{hari}$ menunjukkan secara signifikan pada kelompok kontrol yang perbaikan ukuran luka ulkus dekubitus. ${ }^{20}$

Penelitian ini menunjukkan adanya hubungan sedang $(\mathrm{r}=0.4-0.6)$ antara angka kecukupan protein dengan kesembuhan luka $(\mathrm{r}=0.42)$ ditunjukkan berdasarkan analisis bivariat (Tabel. 9). Angka kecukupan protein pada penelitian ini dinilai dari retata asupan protein per hari dihitung dari jumlah asupan protein dibagi tujuh yaitu selama rentang waktu pengamatan.Hal ini sesuai dengan rekomendasi dari NPUAP/EPUAP dan studi penelitian lain yang menunjukkan kebutuhan asupan protein ulkus dekubitus berkisar 1.25-1.5 gr/kgBB/hari dimana penderita ulkus dekubitus derajat III-IV dapat mencapai 1.5-2 gr/kgBB/hari. ${ }^{1,7,8}$

Pemenuhan kebutuhan protein penting dalam fase penyembuhan luka yang meliputi proliferasi fibroblas, sintesis kolagen, angiogenesis, dan fungsi imun. Protein yang diberikan dalam bentuk potein utuh, protein terhidrolisir, dan asam amino. Pasien dengan kondisi ulkus dekubitus kronis kehilangan protein melalui eksudat luka yang menyebabkan penurunan 
pembentukan kolagen dan menghambat kesembuhan luka. ${ }^{1,5,9}$

Studi penelitian yang dilakukan Takahiro terhadap 40 subjek dengan ulkus dekubitus menunjukkan bahwa kelompok yang mengalami kesembuhan luka selalu mendapatkan asupan protein minimal 45 $\mathrm{gP} /$ hari dan kelompok yang tidak mengalami atau perburukan kesembuhan luka mendapatkan asupan protein sekitar 20 $\mathrm{gP} /$ hari. $^{5}$

Hasil penelitian angka kecukupan protein pada penelitian ini sejalan dengan penelitian yang dilakukan Crowe $\mathrm{T}$ dan Brookbank $\mathrm{C}$ yang menunjukkan bahwa kelompok yang asupan protein $<1.2$ gr/kgBB/hari menunjukkan kesembuhan luka dua kali lipat lebih rendah dibandingkan kelompok yang mendapatkan asupan protein lebih tinggi dari 1.2 gr/kgBB/hari. ${ }^{1}$ Evaluasi intervensi gizi terhadap kesembuhan luka pada ulkus dekubitus dengan studi kontrol acak yang dilakukan pada tahun 2011 membandingkan pemberian rata-rata protein sebesar 1.24 $\mathrm{gP} / \mathrm{kgBB} /$ hari pada kelompok kontrol dan $1.62 \mathrm{gP} / \mathrm{kgBB} / \mathrm{hari}$ pada kelompok perlakuan menunjukkan secara signifikan perbaikan ukuran luka ulkus dekubitus pada kelompok perlakuan. ${ }^{20}$

Hasil analisis multivariat angka kecukupan energi menunjukkan kontribusi sebesar $11 \%$ terhadap kejadian kesembuhan luka yang dikontrol dengan penilaian skor PUSH H-0. Kebutuhan energi yang diberikan terdiri dari 55\%-60\% karbohidrat, $20-25 \%$ protein, dan $20 \%$ lemak dalam mencukupi kebutuhan makronutrien. Peran gizi dengan pemenuhan kecukupan energi digunakan dalam aktivitas enzim heksokinase dan sintesis sitrat yang dibutuhkan dalam fase kesembuhan luka. ${ }^{7}$

Faktor-faktor lain yang dapat mempengaruhi kesembuhan luka adalah pemakaian obat-obatan seperti kortikosteroid, terapi radiasi atau kemoterapi, faktor komorbid penyakit lain, dan kecukupan dari mikronutrien yang berperan dalam proses kesembuhan luka. $1,7,11-15$

Angka kecukupan protein memiliki kontribusi sebesar $18 \%$ terhadap kejadian kesembuhan luka yang dikontrol dengan PUSH skor H-0 berdasarkan analisis penelitian ini. Banyak studi penelitian yang menunjukkan pentingnya peran gizi dalam pemenuhan kecukupan protein dalam proses kesembuhan luka yang meliputi proliferasi sel terutama sintesis fibroblas dan kolagen. Bentuk polipeptida, dipeptida, dan asam amino seperti leusin, arginin, dan glutamin memiliki efek anabolik yang merangsang terjadinya proses kesembuhan luka. ${ }^{7,11-15}$ 
Hasil penelitian ini sesuai dengan panduan EPUAP dimana kebutuhan energi pada proses kesembuhan luka pada pasien dengan ulkus dekubitus dikatakan adekuat bila memenuhi $30 \mathrm{kkal} / \mathrm{kgBB} / \mathrm{hari}$ dan kebutuhan protein secara umum untuk kesembuhan luka berdasarkan panduan NPUAP/EPUAP pada ulkus dekubitus yaitu 1.25-1.5 g/kgBB/hari. ${ }^{1,7,8}$

Keterbatasan penelitian ini adalah belum mempertimbangkan angka kecukupan mikronutrien seperti zink, vitamin $\mathrm{C}$, dan vitamin $\mathrm{A}$ dalam proses kesembuhan luka pada ulkus dekubitus. Penelitian ini menggunakan lingkar lengan atas sebagai pengukuran berat badan dan jangka waktu evaluasi penilaian kesembuhan luka yang terbatas yang merupakan kelemahan penelitian ini. Faktorfaktor lain yang dapat mempengaruhi kesembuhan luka pada ulkus dekubitus yaitu pemakaian obat-obatan (kortikosteroid, terapi radiasi/kemoterapi), faktor komorbid penyakit lain, mobilisasi, dan komposisi tubuh dimana angka kecukupan energi berkontribusi sebesar $11 \%$ dan angka kecukupan protein sebesar $18 \%$ terhadap kejadian kesembuhan luka yang dikontrol dengan penilaian PUSH skor $\mathrm{H}-0$.

\section{Simpulan}

Simpulan yang dapat diambil dari penelitian ini adalah :
1. Terdapat hubungan bermakna antara angka kecukupan energi dan protein dengan kesembuhan luka pada pasien ulkus dekubitus.

2. Faktor usia, indeks massa tubuh, dan adanya infeksi pada ulkus dekubitus bukan merupakan variabel perancu terhadap kesembuhan luka pada pasien ulkus dekubitus dalam penelitian ini. Skor PUSH H-0 berhubungan dengan kesembuhan luka pada pasien ulkus dekubitus. Angka kecukupan energi dan angka kecukupan protein berhubungan dengan kesembuhan luka pada pasien ulkus dekubitus setelah dikontrol oleh skor PUSH H-0.

\section{Saran}

Penelitian ini belum mempertimbangkan angka kecukupan mikronutrien seperti zink, vitamin $\mathrm{C}$, dan vitamin A dalam proses kesembuhan luka pada pasien ulkus dekubitus sehingga disarankan dapat menjadi dasar pertimbangan pada penelitian selanjutnya. Pengunaan bioimpedance analysis untuk mengukur komposisi tubuh dan jangka waktu evaluasi penilaian kesembuhan luka yang lebih lama disarankan dalam melakukan penelitian selanjutnya. 


\section{Konflik Kepentingan}

Penulis tidak memiliki konflik kepentingan dalam penelitian ini.

\section{Kontribusi Penulis}

Penulis 1 - Nathalia Safitri pengembangan studi penelitian, pengumpulan data, analisis data, dan publikasi manuskrip.

Penulis 2 - Hertanto Wahyu Subagio pengembangan studi penelitian, pengumpulan data, dan analisis data.

Penulis 3 - Etisa Adi Murbawani pengembangan studi penelitian. pengumpulan data, dan analisis data.

Penulis 4 - Niken Puruhita pengembangan studi penelitian dan analisis data.

Penulis 5 - Amalia Sukmadianti engembangan studi penelitian dan analisis data.

\section{Daftar Pustaka}

1. Seied Hadi Saghaleini, Kasra Dehghan, I Kamran Shadvar, Sarvin Sanaie, II Ata Mahmoodpoor. Pressure Ulcer and Nutrition. Press Ulcer Nutr. 2018;22(4):283-9.

2. Vangilder C, Macfarlane GD. Results of Nine International Pressure Ulcer Prevalence Surveys: 1989 to 2005 . Ostomy wound Manag. 2008;54(2):40-54.

3. Mutia LKAD. Profil Penderita Ulkus Dekubitus yang Menjalani Tirah Baring di Ruang Rawat Inap RSUD Arifin Achmad Provinsi Riau Periode Januari 2011Desember 2013. JOM FK. 2015;2(2):1-11.

4. Agrawal K, Chauhan N. Pressure Ulcers : Back to basic. Indian $\mathrm{J}$ Plast Surg. 2012;45(2):244-54.

5. Yamamoto Takahiro, Masaki Fujioka,Riko Kitamura, Yoshinori Katagiri, Hiroyo Nagatomo. Evaluation of Nutrition in the Healing of Pressure Ulcers: Are the EPUAP Nutritional Guidelines sufficient to heal wounds? wounds. 2009;21(6):153-7.

6. Gunes UY. A Prospective Study Evaluating the Pressure Ulcer Scale for Healing (PUSH Tool) to assess stage II, stage III, and stage IV pressure ulcers. Ostomy Wound Manag. 2009;55(5):48-52.
7. Demling RH. Nutrition, Anabolism, and the Wound Healing Process: an Overview. Eplasty [Internet]. 2009;9(2):65-94. Available from: http://www.ncbi.nlm.nih.gov/pubmed/1927 4069\%0Ahttp://www.pubmedcentral.nih.g ov/articlerender.fcgi?artid=PMC2642618

8. Broughton G, Janis JE, Attinger CE. The Basic Science of Wound Healing. Plast Reconstr Surg. United States; 2006 Jun;117(7):12S-34S.

9. Sorg H, Tilkorn DJ, Mirastschijski U, Hager S. Skin Wound Healing: An Update on the Current Knowledge and Concepts. Eur Surg Res. 2017;58:81-94.

10. Grey JE, Enoch S, Harding KG. Wound Assessment. BMJ. 2006;332(7536):285-8.

11. Guo S, DiPietro LA. Factors Affecting Wound Healing. J Dent Res. 2010;89(3):219-29.

12. Broughton II G, Janis J.E AC. Wound Healing: An Overview. CME. 2006;117(1e-S):1-32.

13. Rodeheaver $\mathrm{C}$, Theodore $\mathrm{G}$. Use of the PUSH Tool to Measure Venous Ulcer Healing. Ostomy Wound Manag. 2005;51(5):58-60,62-3.

14. Stevens DL, Bisno AL, Chambers HF, Dellinger EP, Goldstein EJC, Gorbach SL, et al. Practice Guidelines for the Diagnosis and Management of Skin and Soft Tissue Infections : 2014 Update by the Infectious Diseases Society of America. Chronic Infect Dis. 2014;59(July):26.

15. Anderson K, Hamm RL. Factors That Impair Wound Healing. J Am Coll Clin Wound Spec [Internet]. Mosby, Inc; 2014:4(4):84-91. Available from: http://dx.doi.org/10.1016/j.jccw.2014.03.0 01

16. McDaniel J.C BK. Smoking, Chronic Wound Healing, and Implications for Evidence-Based Practice. J Wound Ostomy Cont Nurs. 2014;41(5):415-E2.

17. Sopiyudin. Besar Sampel dan Cara Pengambilan Sampel. Jakarta: Salemba Medika; 2013. 19-22 p.

18. Gibson R. Principles of Nutritional Assessment. 2nd ed. London: Oxford University Press Inc; 2005. 58-62 p.

19. Sudigdo S. Dasar-dasar Metodologi Penelitian Klinis. Edisi ke 5. Jakarta: 
Sagung Seto; 2014. p. 130-144;352-384.

20. Ohura T, Nakajo T, Okada S, Omura K, Adachi K. Evaluation of Effects of Nutrition Intervention on Healing of
Pressure Ulcers and Nutritional States (Randomized Controlled Trial). Wound Repair Regen. 2011;19(3):330-6. 
Tabel 1. Data karakteristik subjek penelitian

\begin{tabular}{llll}
\hline \multirow{2}{*}{ Variabel (n= 40) } & & n & \% \\
\hline Jenis Kelamin & Laki - laki & 18 & 45 \\
Kategori IMT & Wanita & 22 & 55 \\
& Berat badan kurang & 19 & 47.5 \\
& Berat badan normal & 9 & 22.5 \\
& Berat badan berlebih & 4 & 10 \\
Derajat ulkus dekubitus & Obesitas & 8 & 20 \\
& Ukus derajat 1 & 23 & 57.5 \\
Infeksi & Ukus derajat 2 & 13 & 32.5 \\
& Ukus derajat 3 & 4 & 10 \\
Angka kecukupan energi & Infeksi & 17 & 42.5 \\
& Tanpa infeksi & 23 & 57.5 \\
Angka kecukupan protein & $<30$ kkal/kgBB/hari & 13 & 32,5 \\
& $\geq 30$ kkal/kgBB/hari & 27 & 67.5 \\
Diagnosis & <1,2 g/kgBB/hari & 16 & 40 \\
& $\geq 1,2$ g/kgBB/hari & 24 & 60 \\
& Space occuping lession & 3 & 7.5 \\
& Stroke & 10 & 25 \\
& Vertebral discus disorders & 3 & 7.5 \\
& Kanker & 5 & 12.5 \\
& Lain-lain (fraktur, penyakit kritis,hepatitis, & 19 & 47.5 \\
& tuberkulosis paru, & & \\
\hline
\end{tabular}

Tabel 2. Distribusi variabel penelitian

\begin{tabular}{|c|c|c|}
\hline Variabel $(n=40)$ & Mean \pm SD & Median $(\min -$ maks $)$ \\
\hline Usia (tahun)* & $43.2 \pm 12.64$ & $47(18-60)$ \\
\hline Berat badan (Kg) & $50.7 \pm 11.67$ & $51(27-70)$ \\
\hline Tinggi badan $(\mathrm{cm})$ & $158.2 \pm 5.98$ & $157.5(149-174)$ \\
\hline $\operatorname{IMT}\left(\mathrm{Kg} / \mathrm{m}^{2}\right)$ & $20.3 \pm 4.33$ & $18.92(11.84-29.37)$ \\
\hline Skor PUSH H-0 & $10.1 \pm 3.6$ & $10(4-17)$ \\
\hline Skor PUSH H-7* & $7.9 \pm 3.56$ & $7.5(3-15)$ \\
\hline $\begin{array}{l}\text { Angka kecukupan energi } \\
\text { (kkal/kgBB/hari) }\end{array}$ & $30.8 \pm 7.35$ & $30(15-45)$ \\
\hline Angka kecukupan protein (g/kgBB/hari)* & $1.2 \pm 0.25$ & $1.2(0.6-1.5)$ \\
\hline Kesembuhan luka* & $2.2 \pm 0.90$ & $2(1-4)$ \\
\hline Jumlah leukosit $(/ \mu \mathrm{L})^{*}$ & $10817.5 \pm 2863.47$ & $9900(6800-17800)$ \\
\hline
\end{tabular}

Catatan: SD (standar deviasi); min (minimal); maks (maksimal), *Distribusi data tidak normal, IMT, indeks massa tubuh. 
Tabel 3. Analisis bivariat

\begin{tabular}{lcc}
\hline \multirow{2}{*}{ Variabel } & \multicolumn{2}{c}{ Kesembuhan luka } \\
\hline Usia (tahun) & r & $\boldsymbol{p}$ \\
Berat badan $(\mathrm{Kg})$ & 0.13 & 0.43 \\
Tinggi badan $(\mathrm{cm})$ & -0.04 & 0.81 \\
IMT $\left(\mathrm{Kg} / \mathrm{m}^{2}\right)$ & -0.12 & 0.45 \\
Skor PUSH H-0 & -0.03 & 0.86 \\
Skor PUSH H-7 & 0.20 & 0.21 \\
Angka kecukupan energi $(\mathrm{kkal} / \mathrm{kgBB} / \mathrm{hari})$ & -0.04 & 0.82 \\
Angka kecukupan protein $(\mathrm{g} / \mathrm{kgBB} / \mathrm{hari})$ & 0.37 & $0.02^{*}$ \\
Jumlah leukosit $(/ \mu \mathrm{L})$ & 0.42 & $0.01^{*}$ \\
\hline Uji $S p e$ r & 0.07 & 0.69 \\
\hline
\end{tabular}

Uji Spearman Rho, ${ }^{* *}$ signifikan $p<0.05$

Tabel 4. Analisis multivariat angka kecukupan energi terhadap kesembuhan luka

\begin{tabular}{lcccc}
\hline \multicolumn{1}{c}{ Konstanta } & a & Std. error & $\boldsymbol{p}$ & $\boldsymbol{\beta}$ \\
\hline Skor PUSH H-0 & 0.04 & 0.04 & 0.27 & 0.17 \\
$\begin{array}{l}\text { Angka kecukupan Energi } \\
\text { (kkal/kgB/hari) }\end{array}$ & 0.04 & 0.02 & 0.03 & 0.34 \\
\hline
\end{tabular}

*Adj. $\mathrm{R}^{2}=0.11$

Tabel 5. Analisis multivariat angka kecukupan protein terhadap kesembuhan luka

\begin{tabular}{lllll}
\hline Konstanta & $\mathbf{a}$ & Std. error & $\boldsymbol{p}$ & $\boldsymbol{\beta}$ \\
\hline Skor PUSH H-0 & 0.04 & 0.04 & 0.24 & 0.17 \\
$\begin{array}{l}\text { Angka kecukupan Protein } \\
\text { (gr/kgBB/hari) }\end{array}$ & 1.524 & 0.53 & 0.01 & 0.42 \\
\hline
\end{tabular}

*Adj. $\mathrm{R}^{2}=0.18$ 